\title{
Laboratory studies of the algaecide GreenTD: stability, algaecidal activity and reduction of microcystin production
}

\author{
II Kyu Cho ${ }^{1^{*}+}$ (D), Jae Ung Seol ${ }^{1 \dagger}$, Md. Musfiqur Rahman ${ }^{1}$, Dong-Gi Lee ${ }^{1}$, Hyeongkyu Son ${ }^{2}$ and Hoon Cho ${ }^{2}$
}

\begin{abstract}
GreenTD (Dichlorobenzyl derivative, MW 362.17) is a new dichlorobenzyl derivative algaecide. It is effective and selective against harmful algal blooms (HABs). HABs cause serious problems for public health and fishery industries. Algae that cause HABs include Microcystis spp., Anabaena spp., and Aphanizomenon spp. Blooms of toxin-producing Microcystis aeruginosa occur regularly in fresh water where is rich in nitrogen and phosphorus nutrients. Environmental fate studies are needed to investigate the degradation of GreenTD. In the present study, we studied the persistence of GreenTD ( $90 \%$ aqueous solution) in water and toxic effects GreenTD on M. aeruginosa and reduction of microcystin production in the culture media. GreenTD was added in the water pots and microcystis media tubes at levels of $25 \mathrm{~g} / 0.1 \mathrm{ha}(0.5 \mathrm{mg} / \mathrm{kg})$ and $50 \mathrm{~g} / 0.1 \mathrm{ha}(1.0 \mathrm{mg} / \mathrm{kg})$. Samples were collected after 1, 3, 5, 7 and 14 days. The residues of GreenTD and microcystins in water and the media were determined using high performance liquid chromatography-diode array detection and ultra-performance liquid chromatography-tandem mass spectrometry, respectively. The half-life of GreenTD at concentrations of 0.5 and $1.0 \mathrm{mg} / \mathrm{kg}$ was 4.5 and 3.6 days, respectively. This result presents a safety level suitable for the acceptable guideline of water residue. The average recoveries of microcystins RR, YR, $L R$, and $L A$ were $106-115 \%, 103-110 \%, 96-105 \%$ and $89-113 \%$ in the microcystis media, respectively. The limit of detection of (LOD) the microcystins was $0.1 \mathrm{\mu g} / \mathrm{kg}$. No microcystins in the media were detected at the LOD $(0.1 \mu \mathrm{g} /$ $\mathrm{kg}$ ). GreenTD at concentrations of 0.2 and $0.5 \mu \mathrm{g} / \mathrm{kg}$ had a $100 \%$ of control efficacy of M. aeruginosa. No growth of the blue-green algae was observed after 14 days of GreenTD application.
\end{abstract}

Keywords: GreenTD, Blue-green algae, Microcystins, UPLC-MS/MS

\section{Introduction}

Harmful algal blooms (HABs) previously known as red tide are now a worldwide marine environmental concern as they produce toxins hazardous for the marine eco-system [1]. An excess amount of nitrogen and phosphorus based nutrients, high water temperature, light intensity and stable conditions are the promoting parameters for the formation of HABs via natural photosynthesis $[2,3]$.

\footnotetext{
*Correspondence: ilkyucho@naver.com

${ }^{\dagger}$ Il Kyu Cho and Jae Ung Seol equally contributed to this paper as first authors

${ }^{1}$ Eco-Friendly Agri-Bio Research Center, Jeonnam Bioindustry Foundation, 495 Immyeon-ro, Gokseong, Jeonnam 57510, South Korea Full list of author information is available at the end of the article
}

In 1972, red tide was observed to disperse and stimulated throughout the region via tropical storm at United States [1]. In 1970, red tide was found at the east coast of Tasmania and then dispersed to the mainland Australia [1]. Bloom of the dinoflagellate was observed at the coastal region of Japan and Hong Kong that caused mass mortalities of oysters short-necked clams [4]. In 1970s, HABs were occasionally observed at the inner bay of the Korean coastal region. HABs started spreading in 1980, while it was observed everywhere in the Korean coastal region in 1990. In 1995 the estimated losses resulted by HABs were 60 million U.S. dollars to the Korean aquaculture industry $[4,5]$. Due to climate change, species that were the source of red tide were also changed from diatom to flagella and dinoflagellate. Heterocapsa 
circularisquama is one of the harmful algae that have been associated with shellfish mortality [6]. Moreover, during algal blooms, a large amount of microcystin can be produced by cyanobacteria that cause great environmental risks during water supply for drinking and irrigation [7]. So far, more than 50 microcystins have been found and the most common microcystins are microcystin-RR, -YR, -LR, and -LA. Besides that, HABs can directly affect the human health as large portions of human diet are collected from the marine sources. Therefore, HABs are responsible for huge economic losses and environmental damages.

Several ways such as applications of biological agents, clay flocculants, chemical algaecides, and physical manipulation have been utilized to control HABs [8-14]. Among them, application of chemical algaecide is considered as an effective and popular technique $[15,16]$. In order to inhibit the growth of HABs species, the design of a selective and eco-friendly chemical agents are the interest of present research [6]. Thiazolidinedione derivatives have been screened against the growth of HAB species and TD49 was found as an effective algicide against HABs $[17,18]$.

In order to provide guidelines for the safe use of the aquatic chemicals, ecological risk assessments (ERAs) for chemical contaminants are operated mainly to investigate the maximum environmental concentrations that do not have any adverse ecological effects [4]. Therefore, attention should be given for analysis of residual chemicals in aquatic ecosystems during ERA as an uncounted amount of residue may provide wrong information on toxicity prediction [19].

GreenTD (Dichlorobenzyl derivative, MW 362.17) is a new dichlorobenzyl derivative algaecide that was developed by Curearth (Gwangju, Korea) [20]. It is effective and selective against HABs. HABs cause serious problems for public health and fishery industries. The $\mathrm{LD}_{50}$ and acceptable daily intake (ADI) of GreenTD was $2000 \mathrm{mg} / \mathrm{kg}$ bw and $90 \mathrm{mg} / \mathrm{kg}$ bw/day, respectively. The safe application of the product was mentioned as $0.1 \sim 0.5 \mathrm{ppm}$ [20]. However, the persistence information of the algaecide in an aquatic environment is needed for the ERA. Few published methods were reported to determine GreenTD using HPLC-UVD [21], although several analytical methods have been available for the analysis of four microcystins using LC-MS/MS [22-24]. Therefore, the aim of the present study was to develop an analytical method for the algaecide GreenTD and observe the inhibition activities of GreenTD on microcystin formation.

\section{Materials and methods \\ Chemicals and reagents}

Analytical standard GreenTD (Dichlorobenzyl derivative, MW 362.17, Purity 99.7\%) was supplied by Curearth (Gwangju, Republic of Korea). The substance of the thiazolidine derivative, GreenTD had been developed by the applied chemical materials lab of Korean Chosun University and then Curearth produced through the mass production process. The chemical structure of GreenTD could not be provided due to intellectual property rights [25]. Methanol, water, and dichloromethane were of HPLC grade and were purchased from Burdick \& Jackson (SK Chemical, Ulsan, Korea). Anhydrous sodium sulfate, trifluoroacetic acid, and sodium chloride were of analytical grade and were supplied by Sigma \& Aldrich Chemical Co. Ltd. (St. Louis, Missouri, United States).

\section{Calibration curve construction}

An amount of $20.1 \mathrm{mg}$ of GreenTD standard (99.7\%) was dissolved in $100 \mathrm{~mL}$ of water to make $200 \mathrm{mg} / \mathrm{L}$ stock solution. The stock solution was diluted with water to make various concentration of working standard solution: $0.1,0.5,1.0,2.5,5.0$ and $10.0 \mathrm{mg} / \mathrm{L}$, and then inject a $20 \mu \mathrm{L}$ into HPLC-DAD (UV $230 \mathrm{~nm}$ ). The calibration curve was prepared based on the peak area of the chromatogram against concentration.

\section{Sampling and treatment}

Distilled water and paddy soil (1062-13, Oji-ri, Ogokmyeon, Gokseong-gun, Jeollanam-do) were used for the study of GreenTD degradation dynamics. The soil characteristics are shown in Table 1. After removing impurities such as stones and debris, paddy soil samples were collected at $10 \mathrm{~cm}$ depth using a soil sampler, mixed well and placed in a bag and transported to the laboratory. This sample was shaded and passed through a $2 \mathrm{~mm}$ sieve to obtain a test sample. The soil sample was then evenly filled in a container $(23.0 \mathrm{~cm} \times 17.0 \mathrm{~cm} \times 13.0 \mathrm{~cm} \mathrm{~h}$. $)$ to a height

Table 1 Physical and chemical properties of soil

\begin{tabular}{|c|c|c|c|c|c|c|}
\hline \multirow[t]{2}{*}{ Soil texture } & \multicolumn{3}{|c|}{ Particle size (\%) } & \multirow[t]{2}{*}{$\mathrm{pH}\left(1: 5 \mathrm{H}_{2} \mathrm{O}\right)$} & \multirow[t]{2}{*}{$O M^{a}(g / k g)$} & \multirow[t]{2}{*}{$\mathrm{CEC}^{\mathbf{b}}(\mathrm{Cmol} / \mathrm{kg})$} \\
\hline & Clay & Silt & Sand & & & \\
\hline Sandy loam & 31.9 & 8.7 & 59.6 & 6.90 & 28 & 7.99 \\
\hline
\end{tabular}

\footnotetext{
a Oganic matter content
}

b Cation exchange capacity 
of $2.5 \mathrm{~cm}$; distilled water was poured so that the height became about $3.0 \mathrm{~cm}$ from the ground. Substances floating on the surface of the water are removed using a fine mesh and left for 3 days, and then the GreenTD 90\% commercial product per pot is treated with a volume of $25 \mathrm{~g} / 10 \mathrm{a}$ and $1.17 \mathrm{mg}$ and $50 \mathrm{~g} / 10 \mathrm{a}$ and $2.34 \mathrm{mg}$. After treatment, distilled water was added so that the water depth became $5 \mathrm{~cm}$, and the surface water level was marked. (The actual weight was $1.0 \mathrm{~kg}$ of soil and $2.0 \mathrm{~L}$ of water.). The algaecide treatment is shown in Table 2.

\section{Sample pre-treatment method for GreenTD Water sample}

The collected water sample was filtered immediately and a $50 \mathrm{~mL}$ portion was concentrate to make $5 \mathrm{~mL}$ using an evaporator under reduced pressure. The sample was then directly injected to HPLC-DAD.

\section{Soil sample}

A $50 \mathrm{~g}$ soil sample was placed in a $500 \mathrm{~mL}$ round bottomed flask to which a $100 \mathrm{~mL}$ of $6 \mathrm{~N}$ sulfuric acid was added. The sample was then refluxed at $180^{\circ} \mathrm{C}$ for $5 \mathrm{~h}$, cool, centrifuge (Hanil Science Industrial, 514R), and alkalinized with $6 \mathrm{~N}$ $\mathrm{NaOH}$. A $50 \mathrm{~mL}$ of water and a $50 \mathrm{~mL}$ of saturated $\mathrm{NaCl}$ solution were added and mix well. A $30 \mathrm{~mL}$ of $\mathrm{CHCl}_{3}$ was added to the mixture and shake well with a mechanical shaker (Eyela, MMV-1000W, Korea) and transfer the upper organic layer to another round bottomed flask after passing through anhydrous $\mathrm{Na}_{2} \mathrm{SO}_{4}$. The addition of $\mathrm{CHCl}_{3}$ step was repeated for 5 more times and combines the organic layer and dried with a rotary evaporator (Buchi Co., R-300, Switzerland). The sample extract was reconstituted in $5 \mathrm{~mL}$ of water.

\section{Blue-Green medium for microsystin formation}

Blue-green medium BG11 was collected from Unipath Ltd, Hants, OPW, UK. A Growth Chamber (Vision, VS91G09M-1300) was used for cell culture at illuminance of 3000 Lux. After microcystis cultivation, $50 \mathrm{ml}$ of the culture solution was confirmed, and then $0.5 \mathrm{ppm}$ and $1.0 \mathrm{ppm}$ of GreenTD were treated (Fig. 1). After application, samples were collected at $0,1,3,5,7,14$, and 21 days and analyzed. The supernatant was collected from the culture solution sample, centrifuged at 12,000 rpm for $2 \mathrm{~min}$, filtered through a 0.45 um GHP syringe filter, and then analyzed by

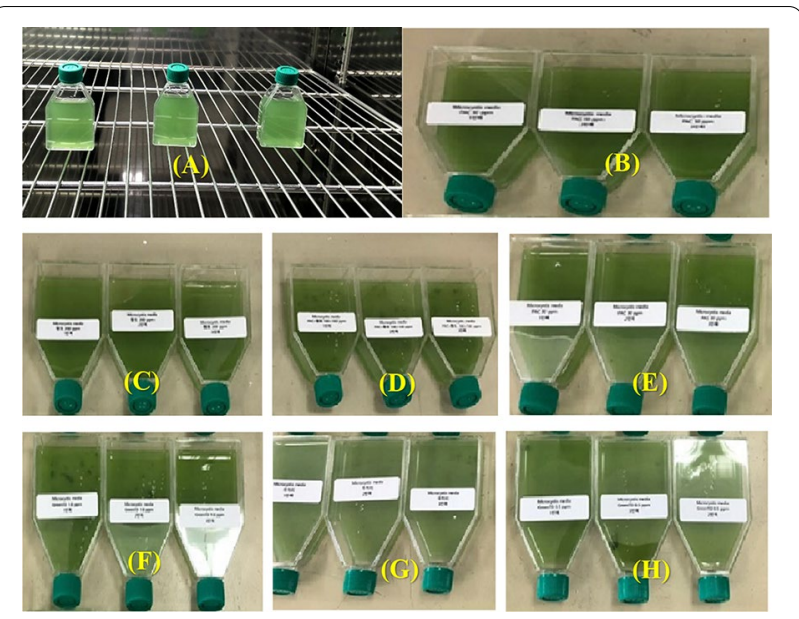

Fig. 1 Treatment pots of test substances after microcystis was grown in blue-green medium. a Microcystis in culture $(50 \mathrm{~mL})$, b Blank (only microcystis), c $0.5 \mathrm{mg} / \mathrm{L}$ of GreenTD, d $1.0 \mathrm{mg} / \mathrm{L}$ of GreenTD, e $30 \mathrm{mg} / \mathrm{L}$ of polyaluminium chloride ([Al(OH)mCl6-m]n, PAC), f; $50 \mathrm{mg} / \mathrm{L}$ of PAC, $\mathbf{g} 200 \mathrm{mg} / \mathrm{L}$ of red clay, $\mathbf{h} 200 \mathrm{mg}$ of PAC and red clay $(\mathrm{V} N, 1: 1)$

injecting $10 \mu \mathrm{L}$ into an ultra-performance liquid chromatograph-tandem mass spectrometer (LC-MS/MS).

\section{Instrument}

Liquid chromatography-diode array detection (LC-DAD)

A Shimadzu LC-2040C MT Plus (Japan) coupled with a diode array detector was employed for GreenTD analysis. Compound was separated on a Shiseido Capcellpak C18 UG $120 \AA(4.6 \times 250 \mathrm{~mm}, 5 \mu \mathrm{m})$ column kept in an oven at $40{ }^{\circ} \mathrm{C}$. A binary mobile phase, A: water with $0.1 \%$ trifluoroacetic acid, and B: methanol with $0.1 \%$ trifluoroacetic acid was flowed with $75 \% \mathrm{~A}$ at $1.5 \mathrm{~mL} / \mathrm{min}$ in an isocratic mode. The injection volume was $20 \mu \mathrm{L}$ and the run time was $15 \mathrm{~min}$. The detection wavelength for GreenTD was $230 \mathrm{~nm}$. Lab solution software was used for data acquisition and processing.

\section{Ultra-performance liquid chromatography-tandem mass spectrometry (UPLC-MS/MS)}

A Waters AQUITY UHPLC system (Waters, Hertfordshire, UK) coupled with an AB SCIEX 4500 QTRAP mass spectrometer (SCIEX, CA, USA) was used for microcystin analysis in multi-reaction monitoring mode. An Ultra Quat column $(50 \mathrm{~mm} \times 2.1 \mathrm{~mm} \times 3 \mu \mathrm{m})$ (Restek, PA,

Table 2 Application information of test substance (90\% Green TD)

\begin{tabular}{lll}
\hline Dosage of treatments & Replicates & Sampling days \\
\hline $25 \mathrm{~g} / 10 \mathrm{a}(0.023 \mathrm{~kg}$ a.i./10 a) & 3 & Before treatment, sampling after 0 (2 $\mathrm{h}$ after treatment $), 1,3,5,714,21 \mathrm{days}$ after application \\
$50 \mathrm{~g} / 10 \mathrm{a}(0.045 \mathrm{~kg}$ a.i./10 a) & & \\
\hline
\end{tabular}


USA) was employed for compound separation. A binary mobile phase contains $0.1 \%$ formic acid in water, $\mathrm{A}$; and $0.1 \%$ formic acid in acetonitrile, $\mathrm{B}$ were flowed in a gradient mode at $0.8 \mathrm{~mL} / \mathrm{min}$. The mobile phase gradient is as follows: at the beginning mobile phase was started with $80 \% \mathrm{~A}$ and kept constant until $1.0 \mathrm{~min}$. At $4.0 \mathrm{~min}$ it was decreased to $60 \% \mathrm{~A}$ and remained unchanged until $6 \mathrm{~min}$. At $6.1 \mathrm{~min}$ the aqueous phase was increased to $80 \% \mathrm{~A}$ and remains same until $7.0 \mathrm{~min}$. The column oven temperature was $40{ }^{\circ} \mathrm{C}$ and the injection volume was $10 \mu \mathrm{L}$. The tandem mass was operated in positive electrospray ionization mode. The ion spray voltage was $5500 \mathrm{v}$ and vaporizer temperature was $450{ }^{\circ} \mathrm{C}$. Nitrogen was used as ion source gas and the pressure was $40 \mathrm{psi}$. Collision gas pressure was $9 \mathrm{psi}$ and curtain gas pressure was $20 \mathrm{psi}$.

\section{Method validation}

In this study, the method validation was partially followed Codex guidelines for agrochemicals [26]. The limit of detection (LOD), limit of quantification (LOQ), linearity, selectivity, accuracy, and precision were taken into account for method development. The LOD is the lowest signal of the analytes that is three times higher than the background noise, whereas, LOQ is the lowest quantitated signal that is 10 times higher than the background noise. Linearity was achieved from the determination coefficient $\left(R^{2}\right)$ resulted from six levels $(0.01,0.05,0.1,0.25$, 0.5 , and $1.0 \mathrm{mg} / \mathrm{kg}$ ) calibration curve for GreenTD and different six concentration levels $(0.0001,0.0003,0.0005$, $0.0008,0.0010$, and $0.0020 \mathrm{mg} / \mathrm{kg}$ ) for microcystins. Selectivity was evaluated from the blank chromatogram where no interferences were observed at the retention time of target analysts. Accuracy was measured from the recovery of fortified standard in two different concentrations. Precision was calculated from the repeatability of three replicated analysis.

\section{Results and discussion Method validation}

The LOD and LOQ were 0.003 and $0.01 \mathrm{mg} / \mathrm{kg}$, respectively, for GreenTD, whereas LOD and LOQ were 0.00003 and $0.0001 \mathrm{mg} / \mathrm{kg}$ for microcystins. The six level calibration curves provide excellent linearity with coefficient of determinants $\left(R^{2}\right) \geq 0.9992$ for GreenTD and $0.9936 \sim 0.9988$ for microcystins (microcystinRR, microcystin-YR, microcystin-LR, microcystinLA). The average recoveries of GreenTD in water and soil were $78.9 \sim 88.2 \%(\mathrm{RSD} \leq 2.95 \%)$ and $76.1 \sim 78.1 \%$ $(\mathrm{RSD} \leq 1.42 \%)$, respectively (Table 3 ). The recoveries of four microcystins were averaged between $73.6 \%$ and $109.6 \%$ with relative standard deviations $\left(R^{2}\right) \leq 9.47$ (Table 4). Mass spectra for microcystins were collected in positive ion mode with a fragmentation voltage of $150 \mathrm{~V}$ (Table 5). The recovery and repeatability of GreenTD and microcystins were in an acceptable range (Recovery $60 \sim 120 \%$ and $\mathrm{RSD}<30 \%$ ) according to Codex guidelines [26].

\section{GreenTD degradation dynamics}

In the water pots and microcystis media tubes, GreenTD was added at levels of $25 \mathrm{~g} / 0.1 \mathrm{ha}(0.5 \mathrm{mg} / \mathrm{kg})$ and $50 \mathrm{~g} / 0.1 \mathrm{ha}(1.0 \mathrm{mg} / \mathrm{kg})$. After $0,1,3,5,7$ and 14 days of application samples were collected and analyzed. The residual degradation dynamic of GreenTD is shown in Fig. 2. As predicted, a slow and steady degradation of the algaecides on the treated pot was monitored as a function of days after treatment. The degradation dynamic of the residue can be explained via first order kinetic model utilizing data linearization by sketching residues versus time. The degradation of GreenTD can be statistically interpreted assuming the residues declined following

Table 4 Limits of quantification, linearity, recovery and repeatability of four microcystins

\begin{tabular}{|c|c|c|c|c|}
\hline \multirow[t]{2}{*}{ Microcystis } & \multirow[t]{2}{*}{ LOQ mg/kg } & \multirow[t]{2}{*}{ Linearity $\left(R^{2}\right)$} & \multicolumn{2}{|c|}{$\begin{array}{l}\text { Average recovery } \\
(\%) \pm \text { RSD }\end{array}$} \\
\hline & & & LOQ & 10 LOQ \\
\hline $\begin{array}{l}\text { Microcystin } \\
\text { RR }\end{array}$ & 0.0001 & 0.9957 & $73.6 \pm 6.09$ & $94.6 \pm 4.59$ \\
\hline MicrocystinYR & & 0.9947 & $101.8 \pm 5.65$ & $101.3 \pm 6.43$ \\
\hline $\begin{array}{l}\text { Microcystin } \\
\text { LR }\end{array}$ & & 0.9936 & $104.4 \pm 5.51$ & $109.6 \pm 4.62$ \\
\hline $\begin{array}{l}\text { Microcystin } \\
\text { LA }\end{array}$ & & 0.9988 & $108.3 \pm 9.47$ & $97.7 \pm 4.96$ \\
\hline
\end{tabular}

Table 3 Limit of detection, fortification concentration, and recovery of GreenTD in water and soil

\begin{tabular}{|c|c|c|c|c|c|c|}
\hline \multirow[t]{2}{*}{ Sample } & \multirow[t]{2}{*}{ Limit of quantification $(\mathrm{mg} / \mathrm{kg})$} & \multirow{2}{*}{$\begin{array}{l}\text { Fortifications (mg/ } \\
\text { kg) }\end{array}$} & \multicolumn{4}{|c|}{ Recovery (\%) } \\
\hline & & & Rep. 1 & Rep. 2 & Rep. 3 & Average (RSD \%) \\
\hline \multirow[t]{2}{*}{ Water } & 0.01 & 0.02 & 88.5 & 87.5 & 88.7 & $88.2(0.73)$ \\
\hline & & 0.10 & 76.3 & 80.8 & 79.6 & $78.9(2.95)$ \\
\hline \multirow[t]{2}{*}{ Soil } & & 0.10 & 76.9 & 79.0 & 78.5 & $78.1(1.40)$ \\
\hline & & 0.50 & 74.9 & 76.4 & 77.0 & $76.1(1.42)$ \\
\hline
\end{tabular}


Table 5 Multiple reaction monitoring (MRM) condition for four microcystins

\begin{tabular}{|c|c|c|c|c|c|c|}
\hline Compound & Precursor ion & Product ion & Dwella $^{a}$ & $C E^{b}$ & $\mathrm{DP}^{\mathrm{c}}$ & $\operatorname{CXP}^{d}$ \\
\hline \multirow[t]{2}{*}{ Microcystin RR } & 519.887 & 135.000 & 150 & 35 & 106 & 10 \\
\hline & 519.887 & 620.300 & 150 & 39 & 106 & 12 \\
\hline \multirow[t]{2}{*}{ Microcystin YR } & 523.354 & 911.300 & 150 & 17 & 71 & 18 \\
\hline & 523.354 & 135.000 & 150 & 17 & 71 & 34 \\
\hline \multirow[t]{2}{*}{ Microcystin LR } & 498.355 & 135.100 & 150 & 17 & 81 & 10 \\
\hline & 498.355 & 861.400 & 150 & 17 & 81 & 18 \\
\hline \multirow[t]{2}{*}{ Microcystin LA } & 910.416 & 776.400 & 150 & 29 & 151 & 16 \\
\hline & 910.416 & 135.100 & 150 & 95 & 151 & 12 \\
\hline
\end{tabular}

a Dwell time means it accumulated counts time (dwell time/integration time)

b Collision energy

c Declustering potential

${ }^{d}$ Collision cell exit potential

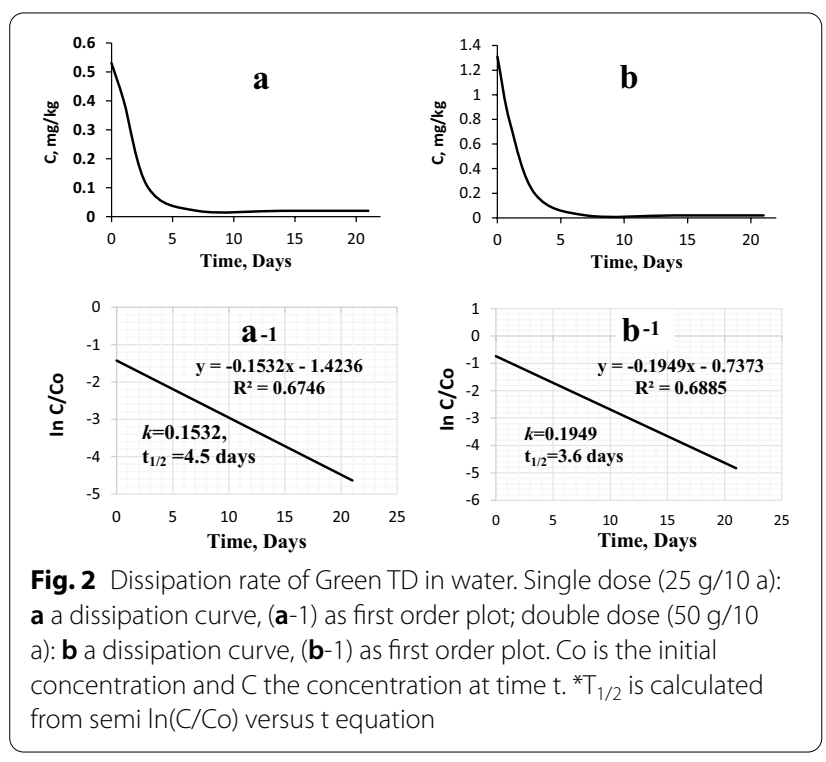

first-order kinetic equation $(\ln C=\ln C o-k t)$, where $C$ is the amount of residues in concentration at a specific time $t$ after application of algaecides, Co is the concentration of residues at 0 days and $\mathrm{k}$ is the rate constant. The determination coefficient $\left(R^{2}\right)$ indicates the dissipation behavior following first order kinetics. The dissipation study provides information about the persistence of the residues that can be observed from half-life $\left(\mathrm{T}_{1 / 2}\right)$ and derived from the equation $0.693 / \mathrm{k}$ [27]. Therefore, at concentrations of $0.5 \mathrm{mg} / \mathrm{kg}$ the half-life of GreenTD was 4.5 days and at $1.0 \mathrm{mg} / \mathrm{kg}$ it was 3.6 days.

\section{Translocation of GreenTD from water to soil}

Green TD was found to move from water to soil after 7 days. The average residues after 21 days was $<0.02 \mathrm{mg} / \mathrm{L}$ for both treatment of $25 \mathrm{~g} / 0.1 \mathrm{ha}$
$(0.5 \mathrm{mg} / \mathrm{kg})$ and $50 \mathrm{~g} / 0.1 \mathrm{ha}(1.0 \mathrm{mg} / \mathrm{kg})$. The total residual amount of Green TD in the soil lower layer were $0.03 \sim 0.47 \mathrm{mg} / \mathrm{kg}$ and $0.05 \sim 0.92 \mathrm{mg} / \mathrm{kg}$, respectively, for the treatment of $25 \mathrm{~g} / 0.1 \mathrm{ha}$ and $50 \mathrm{~g} / 0.1 \mathrm{ha}$.

GreenTD may be leachable in soil, particularly when it is at a high concentration. Most GreenTD in soils are decomposed, while a trace amount is adsorbed. GreenTD may also undergo photolysis and microbial degradation in the environment.

\section{Algae removal efficiency and eco toxicity of GreenTD}

Algae control efficacies were evaluated after treatment of GreenTD at $0.5 \mathrm{mg} / \mathrm{L}$ and $1 \mathrm{mg} / \mathrm{L}$ in indoor and outdoor environments under fluorescent lights. When $1 \mathrm{mg} / \mathrm{L}$ of GreenTD was used, the removal efficiency was higher. There was no significant difference between indoor and outdoor comparative experiments. The results are shown in Table 6. As shown in Table, the outdoor study showed $60.0 \%$ and $60.2 \%$ removal efficiencies after 30 and $60 \mathrm{~min}$, respectively, when using $1 \mathrm{mg} / \mathrm{L}$ of GreenTD. On the other hand, when using $0.5 \mathrm{mg} / \mathrm{L}$ of GreenTD, the removal efficiency was $50.7 \%$ and $51.3 \%$, respectively, after 30 and $60 \mathrm{~min}$. The results indicated a dose-dependent control efficacy of GreenTD for HABs.

Similarly in the case of indoor study, the control efficacy was higher when $1 \mathrm{mg} / \mathrm{L}$ of GreenTD was used compared to $0.5 \mathrm{mg} / \mathrm{L}$. In the indoor environment, when $1 \mathrm{mg} / \mathrm{L}$ of GreenTD was applied, the removal efficiency was $61.3 \%$ and $60.1 \%$ after 30 and $60 \mathrm{~min}$, respectively, whereas, for application of $0.5 \mathrm{mg} / \mathrm{L}$, the efficacy of GreenTD was $46.9 \%$ and $47.4 \%$, respectively that is about $4 \%$ lower efficiency than $1 \mathrm{mg} / \mathrm{L}$.

Algae removal efficiency and ecological toxicity (water flea, luminescent bacteria) evaluation have been 
Table 6 Evaluation of algae removal efficiency and ecotoxicity of GreenTD for outdoor and indoor studies

\begin{tabular}{|c|c|c|c|c|c|}
\hline \multirow[t]{2}{*}{ Evaluation concentration } & \multirow[t]{2}{*}{ Evaluation time } & \multicolumn{2}{|l|}{ Outdoor study } & \multicolumn{2}{|l|}{ Indoor study } \\
\hline & & $\begin{array}{l}\text { Blue-green } \\
\text { algae + GreenTD } \\
0.5 \mathrm{mg} / \mathrm{L}\end{array}$ & $\begin{array}{l}\text { Blue-green } \\
\text { algae+ GreenTD } \\
1 \mathrm{mg} / \mathrm{L}\end{array}$ & $\begin{array}{l}\text { Blue-green } \\
\text { algae + GreenTD } \\
0.5 \mathrm{mg} / \mathrm{L}\end{array}$ & $\begin{array}{l}\text { Blue-green } \\
\text { algae + GreenTD } \\
1 \mathrm{mg} / \mathrm{L}\end{array}$ \\
\hline \multirow[t]{3}{*}{ Algae count (cells/mL) } & Initial & 200,227 & & 163,000 & \\
\hline & $30 \mathrm{~min}$ & 98,880 & 80,100 & 86,500 & 63,000 \\
\hline & $60 \mathrm{~min}$ & 97,600 & 79,600 & 85,800 & 65,100 \\
\hline \multirow[t]{2}{*}{ Removal efficiency (\%) } & $30 \mathrm{~min}$ & 50.7 & 60.0 & 46.9 & 61.3 \\
\hline & $60 \mathrm{~min}$ & 51.3 & 60.2 & 47.4 & 60.1 \\
\hline \multirow[t]{2}{*}{ Daphnia ecological toxicity (TU) } & $30 \mathrm{~min}$ & 0 & 0 & 0 & 0 \\
\hline & $60 \mathrm{~min}$ & 0 & 0 & 0 & 0 \\
\hline \multirow[t]{2}{*}{ Ecotoxicity of luminescent bacteria (TU) } & $30 \mathrm{~min}$ & 0 & 0 & 0 & 0 \\
\hline & $60 \mathrm{~min}$ & 0 & 0 & 0 & 0 \\
\hline
\end{tabular}

conducted in accordance with Article 9 (Substance of registration for Algae remove) and No. 3 (Guidelines for the installation and operation of algae removal facilities and the use of algae removal materials for application) (Additional file 1). With the evaluation of algae removal efficiency, the ecological toxicity was conducted for two species of daphnia and luminescent bacteria in water collected after treatment of 30 and $60 \mathrm{~min}$ of GreenTD. No significant effect was observed in both outdoor and indoor studies.

\section{Microcystin in blue-green medium}

Microcystis, a species of toxin from cyanobacteria, is present in the intracellular cytoplasm. However, microcystins are not discharged into the water system during the active growth of cyanobacteria. When cells die or are destroyed, microcystins are released along with chlorophylla from microcysts. An indoor experiment was carried out where the number of microcystine cells was maintained 200,000, which is similar to algae generated in general rivers, but it was observed that the outflow of microcystine into the water system requires an enzyme

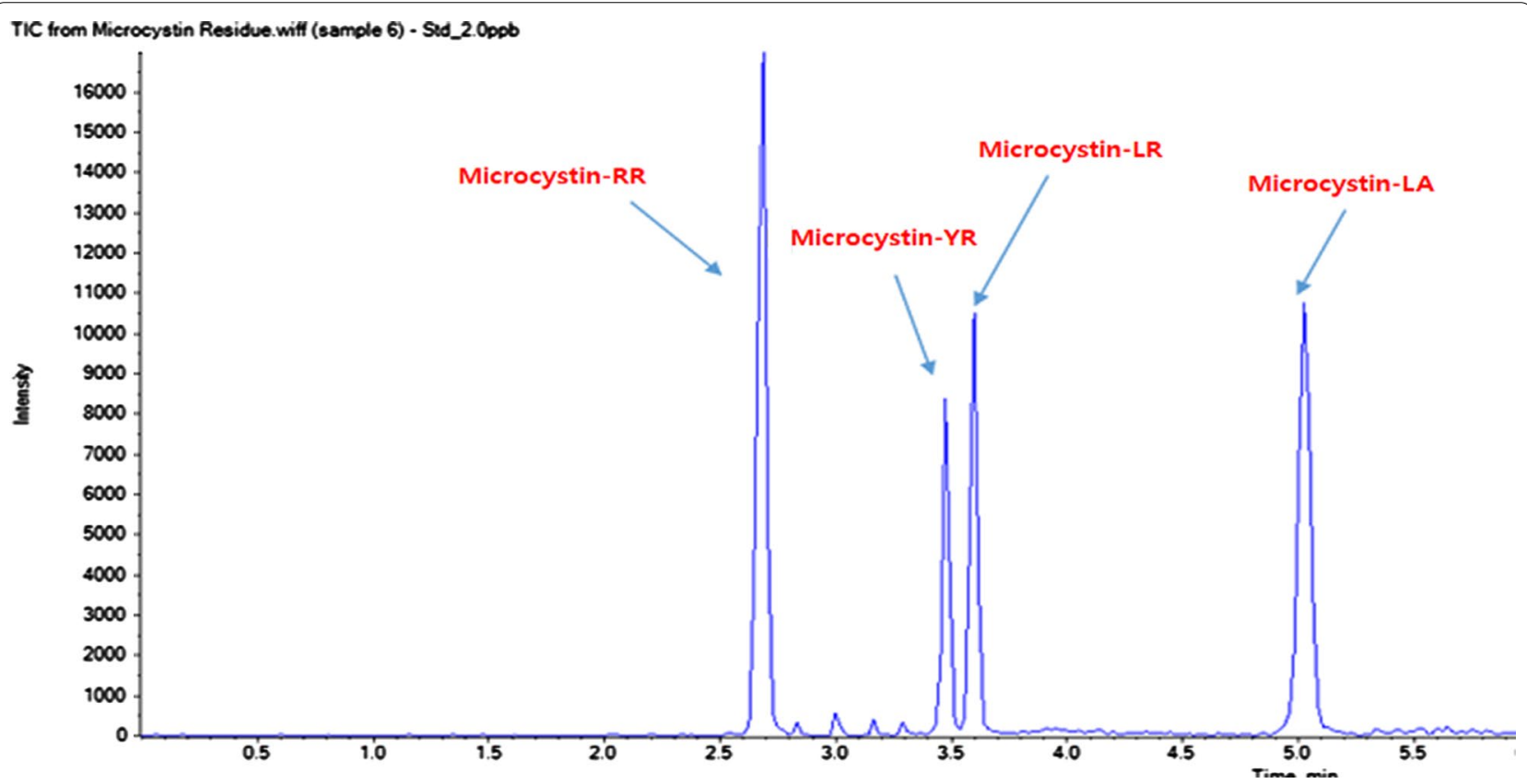

Fig. 3 UPLC-MS/MS chromatogram of four microcystins (Microcystin-RR, Microcystin-YR, Microcystin-LR and Microcystin-LA) 
that acts as a catalyst, and the microcystine inducing substance in the water system is unknown (Fig. 1).

In the present study, the effectiveness of GreenTD was evaluated by performing field tests through green algae production to identify the presence of microcystin and the tendency to increase and decrease after treatment with GreenTD. Therefore, microcystis was cultured in an indoor experimental system and the GreenTD treated $(0.5 \mathrm{ppm}$ and $1.0 \mathrm{ppm})$ cultured samples collected at $0,1,3,5,7,14$, and 21 days were analyzed for four microcystins (Microcystin-RR, LR, LA, and YR) via LC-MS/MS. However, no microcystins were observed at the $0.1 \mathrm{ppb}$ detection level (Fig. 3).

Degradation dynamics and algaecidal activities such as microcystins formation of GreenTD have been studied. Both GreenTD and microcystins provided an acceptable recovery and precision. The half-life of GreenTD for the treatment of 0.5 and $1.0 \mathrm{mg} / \mathrm{kg}$ were found 4.5 and 3.6 days, respectively. No microcystin was formed at the GreenTD treated blue-green media indicated the algaecidal activities of GreenTD. Ecotoxicity studies also indicated about the safety of GreenTD application.

\section{Supplementary Information}

The online version contains supplementary material available at https://doi. org/10.1186/s13765-021-00591-9.

Additional file 1. Algae removal efficiency and ecological toxicity evaluation.

\section{Acknowledgements}

This work was supported in part by the Ministry of SMEs and Startups grant (Project No. P0002898) and the National Institute of Horticultural and Herbal Science (Project No. PJ01364103) RDA, Republic of Korea.

\section{Authors' contributions}

Conceived and designed the experiments: IKC, JUS, D-GL, and MMR. Performed the experiments: IKC, JUS, D-GL and HS. Contributed reagents/materials/analysis tools: IKC, JUS, D-GL, HS and HC. Wrote the paper: IKC, MMR, and JUS. All authors read and approved the final manuscript.

\section{Funding}

Korea Technology and Information Promotion Agency for SMEs (P0002898) \& Rural Development Administration (PJ01364103).

\section{Availability of data and materials}

Not applicable.

\section{Competing interests}

The authors declare that they have no competing interests.

\section{Author details}

${ }^{1}$ Eco-Friendly Agri-Bio Research Center, Jeonnam Bioindustry Foundation, 495 Immyeon-ro, Gokseong, Jeonnam 57510, South Korea. ${ }^{2}$ Department of Biochemical \& Polymer Engineering, Chosun University, 309 Pilmun-daero, Dong-gu, Gwangju 61452, South Korea.

Received: 6 November 2020 Accepted: 11 January 2021 Published online: 11 February 2021

\section{References}

1. Anderson D (2014) HABs in a changing world: a perspective on harmful algal blooms, their impacts, and research and management in a dynamic era of climactic and environmental change. Harmful Algae 2012:3-17

2. Watson SB, Whitton BA, Higgins SN, Paerl HW, Brooks BW, Wehr JD (2015) Chapter 20 - harmful algal blooms. In: Wehr JD, Sheath RG, Kociolek JP (eds) Freshwater Algae of North America, 2nd edn. Academic Press, Boston, pp 873-920

3. Anderson CR, Berdalet E, Kudela RM, Cusack CK, Silke J, O'Rourke E, Dugan D, McCammon M, Newton JA, Moore SK, Paige K, Ruberg S, Morrison JR, Kirkpatrick B, Hubbard K, Morell J (2019) Scaling up from regional case studies to a global harmful algal bloom observing system. Front Mar Sci. https://doi.org/10.3389/fmars.2019.00250

4. Baek SH, Shin HH, Jang MC, Kim SW, Son M, Cho H, Kim YO (2012) Algicidal effects of a newly developed thiazolidinedione derivative, TD49, on dinoflagellate Akashiwo sanguinea. Ocean Polar Res 34:125-135

5. Park TG, Lim WA, Park YT, Lee CK, Jeong HJ (2014) Economic impact, management and mitigation of red tides in Korea. Harmful Algae 30:S131-S143

6. Son M, Baek SH, Shin K, Choi KH, Kim SW, Ryu J, Cho H, Jung SW, Chung IK, Kim YO, Han MS (2015) Effect of the algicide, thiazolidinedione derivative TD49, on microbial communities in a mesocosm experiment. Environ Monit Assess 187:163-173

7. Paerl HW, Huisman J (2009) Climate change: a catalyst for global expansion of harmful cyanobacterial blooms. Environ Microbiol Rep 1:27-37

8. Imai I, Ishida Y, Hata Y (1993) Killing of marine phytoplankton by a gliding bacterium Cytophaga sp., isolated from the coastal sea of Japan. Mar Biol 116:527-532

9. Doucette GJ, McGovern ER, Babinchak JA (1999) Algicidal bacteria active against Gymnodinium breve (Dinophyceae). I. Bacteria isolation and characterization of killing activity. J Phycol 35:1447-1454

10. Schrader KK, Nanayakkara NPD, Tucker CS, Rimando AM, Ganzera M, Schaneberg BT (2003) Novel derivatives of 9,10-anthraquinone are selective algicides against the musty-odor cyanobacterium Oscillatoria perornata. Appl Environ Microbiol 69:5319-5327

11. Sengco MR, Anderson DM (2004) Controlling harmful algal blooms through clay flocculation. J Eukaryot Microbiol 51:169-172

12. Joo JH, Kuang Z, Wang P, Park BS, Patidar SK, Han MS (2017) Ecological assessment of an algaecidal naphthoquinone derivate for the mitigation of Stephanodiscus within a mesocosm. Environ Pollut 229:735-745

13. Joo J-H, Wang P, Park BS, Byun J-H, Choi HJ, Kim SH, Han M-S (2017) Improvement of cyanobacterial-killing biologically derived substances (BDSs) using an ecologically safe and cost-effective naphthoquinone derivative. Ecotoxicol Environ Saf 141:188-198

14. Park BS, Kim S, Kim JH, Kim JH, Han MS (2019) Dynamics of Amoebophrya parasites during recurrent blooms of the ichthyotoxic dinoflagellate Cochlodinium polykrikoides in Korean coastal waters. Harmful Algae 84:119-126

15. Joo JH, Kang YH, Park BS, Park CS, Cho H, Han MS (2016) A field application feasibility assessment of naphthoquinone derivatives for the mitigation of freshwater diatom Stephanodiscus blooms. J Appl Phycol 28:1735-1746

16. Zhang H, Liu J, Yang W, Gao J, Li J (2003) Studies on biquaternary ammonium salt algaecide for removing red tide. Mar Environ Sci 22:68-71

17. Kim SJ, Yim EC, Park IT, Kim SW, Cho H (2011) Comparison of the acute toxicities of novel algicides, thiazolidinediones derivatives TD49 and TD53, to various marine organisms. Environ Toxicol Chem 30:2810-2816

18. Kim YM, Wu Y, Duong TU, Jung SG, Kim SW, Cho H, Jin ES (2012) Algicidal activity of thiazolidinediones derivatives against harmful algal blooming species. Mar Biotechnol 14:312-322

19. Rasmussen JJ, Wiberg-Larsen P, Baattrup-Pedersen A, Cedergreen N, McKnight US, Kreuger J, Jacobsen D, Kristensen EA, Friberg N (2015) The legacy of pesticide pollution: an overlooked factor in current risk assessments of freshwater systems. Water Res 84:25-32

20. GreenTD ${ }^{\circledR}:$ World's first selective Algicide based on medicine for harmful algae. http://www.curearth.com/2020/kr/images/sub/pdf/pdf_eng.pdf

21. Korean report on " 2017 technology transfer commercialization business on Development of algal technology with high selectivity. file:///C:/ Users/user/Downloads/ndsIOrgDocDown(182)\%20(1).pdf 
22. Turner AD, Dhanji-Rapkova M, O’Neill A, Coates L, Lewis A, Lewis K (2018) Analysis of microcystins in cyanobacterial blooms from freshwater bodies in England. Toxins. 10:39

23. Amé M, Galanti L, Menone ML, Gerpe M, Moreno VJ (2010) Wunderlin D Microcystin- $L R,-R R,-Y R$ and $-L A$ in water samples and fishes from a shallow lake in Argentina. Harmful Algae 9:66-73

24. Mbukwa EA, Msagati TA, Mamba BB (2012) Quantitative variations of intracellular microcystin-LR, -RR and -YR in samples collected from four locations in Hartbeespoort Dam in North West Province (South Africa) during the 2010/2011 summer season. Int J Environ Res Public Health 9:3484-3505

25. Lee M, Shin J, Kim JH, Lim YK, Cho H, Baek SH (2018) Selective algicidal effects of a newly developed GreenTD against Red Tide Harmful Alga. Korean J Environ Biol. 36:359-369
26. Codex Alimentarius (2017) Guidelines on performance criteria for methods of analysis for the determination of pesticide residues in food and feed. CAC/GL 90-2017

27. Putnam RA, Nelson JO, Clark JM (2003) The Persistence and degradation of chlorothalonil and chlorpyrifos in a Cranberry Bog. J Agric Food Chem 51:170-176

\section{Publisher's Note}

Springer Nature remains neutral with regard to jurisdictional claims in published maps and institutional affiliations.

\section{Submit your manuscript to a SpringerOpen ${ }^{\circ}$ journal and benefit from:}

- Convenient online submission

- Rigorous peer review

- Open access: articles freely available online

- High visibility within the field

Retaining the copyright to your article

Submit your next manuscript at $\boldsymbol{\nabla}$ springeropen.com 